\title{
Jejunogastric intussusception after Whipple procedure with B-II reconstruction: a case report
}

\author{
Yun-Xiao Lyu ${ }^{1,2^{*}}$ and Yue-Ming $X u^{1}$
}

\begin{abstract}
Background: Jejunogastric intussusception (JGl) is a rare but severe complication after gastric surgery. JGI can occur from a few days to 55 years postoperatively and has a reported incidence of $<0.1 \%$ in patients who undergo gastric surgery. We firstly report a male patient with duodenal cancer who underwent Whipple's procedure with side-to-side gastrojejunostomy and who subsequently developed JGl. A literature review is provided.

Case presentation: A 68-year-old man was admitted to our emergency department with left upper quadrant abdominal pain and hematemesis of $4 \mathrm{~h}^{\prime}$ duration. He had undergone Whipple's procedure (duct-to-mucosa pancreaticojejunostomy and side-to-side gastrojejunostomy) with B-II reconstruction for duodenal papillary adenocarcinoma 5 years earlier. His vital signs were stable with a blood pressure of 163/93 $\mathrm{mmHg}$, temperature of $37.0^{\circ} \mathrm{C}$; and heart and respiratory rates of $86 \mathrm{per} / \mathrm{min}$ and $20 \mathrm{per} / \mathrm{min}$, respectively. Physical assessment showed mild tenderness in the left upper quadrant, only. A complete blood count showed white cell and platelet counts of $11.69 \times 10^{3} / \mathrm{L}$ and $196 \times 10^{3} / \mathrm{L}$, respectively, and a hemoglobin level of $13.5 \mathrm{~g} / \mathrm{L}$. Abdominal computed tomography (CT) suggested a retrograde intussusception of the intestines into the stomach with dilatation of the remnant stomach. The patient immediately underwent exploratory laparotomy, which revealed a 20-cm retrograde efferent limb at the remnant stomach that had travelled through the previous gastrojejunostomy. There was no evidence of malignancy. We manually reduced the intussuscepted loop using gentle traction, and the viability of the intestinal loop was preserved. The patient had an uneventful postoperative recovery.
\end{abstract}

Conclusion: JGI is a rare but potentially fatal complication after gastric surgery, especially following Whipple's procedure. Early diagnosis and treatment are crucial, and surgery is considered the most effective treatment for JGl.

Keywords: Jejunogastricintussuception, Whipple, Complication

\section{Background}

Jejunogastric intussusception (JGI) is a rare but severe complication after gastric surgery. JGI can occur from a few days to 55 years postoperatively and has a reported incidence of $<0.1 \%$ in patients who undergo gastric surgery [1-3]. The clinical presentations of JGI vary;

\footnotetext{
* Correspondence: Ivyunxiao1986@gmail.com

'Department of Hepatobiliary Surgery, Dongyang People's Hospital, No. 60, West Wuning Road, Dongyang, Jinhua, Zhejiang, China

2Department of General Surgery, DongyangPeople's Hospital, No. 60, West Wuning Road, Dongyang 322100, Zhejiang Province, China
}

however, surgery is the standard treatment, and endoscopy has been used in a small number of patients $[4,5]$. Fewer than 200 cases of postoperative JGI have been reported. We report a male patient with duodenal cancer who underwent Whipple's procedure with side-to-side gastrojejunostomy and who subsequently developed JGI.

\section{Case presentation}

A 68-year-old man was admitted to our emergency department with left upper quadrant abdominal pain and hematemesis of $4 \mathrm{~h}$ duration. $\mathrm{He}$ had undergone

(c) The Author(s). 2020 Open Access This article is licensed under a Creative Commons Attribution 4.0 International License, which permits use, sharing, adaptation, distribution and reproduction in any medium or format, as long as you give appropriate credit to the original author(s) and the source, provide a link to the Creative Commons licence, and indicate if changes were made. The images or other third party material in this article are included in the article's Creative Commons licence, unless indicated otherwise in a credit line to the material. If material is not included in the article's Creative Commons licence and your intended use is not permitted by statutory regulation or exceeds the permitted use, you will need to obtain permission directly from the copyright holder. To view a copy of this licence, visit http://creativecommons.org/licenses/by/4.0/ The Creative Commons Public Domain Dedication waiver (http://creativecommons.org/publicdomain/zero/1.0/) applies to the data made available in this article, unless otherwise stated in a credit line to the data. 
Whipple's procedure (duct-to-mucosa pancreaticojejunostomy and side-to-side gastrojejunostomy) with B-II reconstruction for duodenal papillary adenocarcinoma 5 years earlier. His vital signs were stable with a blood pressure of $163 / 93 \mathrm{mmHg}$, temperature of $37.0^{\circ} \mathrm{C}$; and heart and respiratory rates of $86 \mathrm{per} / \mathrm{min}$ and $20 \mathrm{per} /$ min, respectively. Physical assessment showed mild tenderness in the left upper quadrant, only. A complete blood count showed white cell and platelet counts of $11.69 \times 10^{3} / \mathrm{L}$ and $196 \times 10^{3} / \mathrm{L}$, respectively, and a hemoglobin level of $13.5 \mathrm{~g} / \mathrm{L}$. Abdominal computed tomography (CT) suggested a retrograde intussusception of the intestines into the stomach with dilatation of the remnant stomach (Figs. 1 and 2). The patient immediately underwent exploratory laparotomy, which revealed a $20-\mathrm{cm}$ retrograde efferent limb at the remnant stomach that had travelled through the previous gastrojejunostomy (Fig. 3). There was no evidence of malignancy. We manually reduced the intussuscepted loop using gentle traction, and the viability of the intestinal loop was preserved. The patient had an uneventful postoperative recovery.

\section{Discussion and conclusions}

Jejunogastric intussusception (JGI) is a rare complication after gastric surgery and was first reported in 1914 by Bozzi [6]. JGI can occur at any gastric anastomosis including following gastrojejunal anastomosis and Braun's anastomosis in Billroth II reconstruction, and at the Y anastomosis site in Roux-en-Y reconstruction [7]. The primary disease prior to gastric surgery can include gastric cancer or gastric ulcer [8-13]; however, with

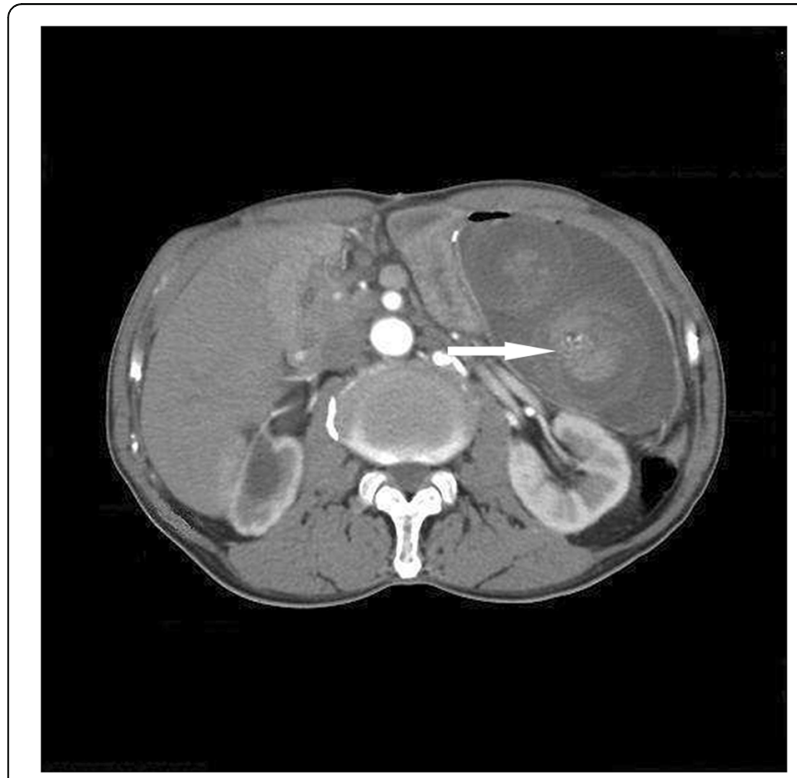

Fig. 1 Abdominal CT scan. The CT-scan reveals dilated stomach with bowel loops (Arrow: jejunogastric intussusception)

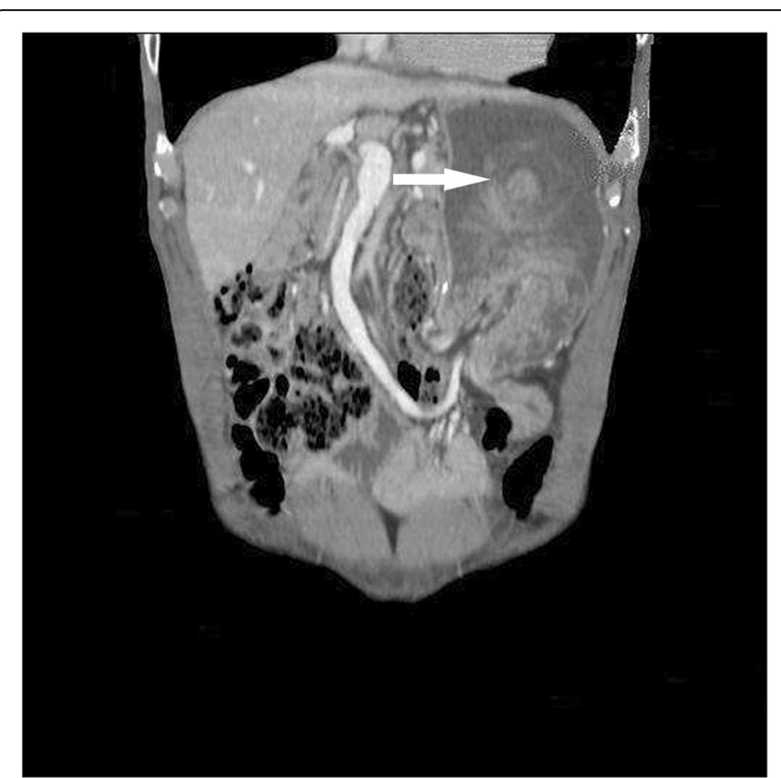

Fig. 2 Abdominal CT scan. Another section showed loop of jejunum in the body of stomach (Arrow: jejunogastric intussusception)

increasing numbers of bariatric surgeries, the incidence of JGI is also increasing [14]. To our knowledge, ours is the first report of JGI after Whipple's procedure.

JGI can have varied clinical presentations such as abdominal pain, vomiting, intestinal obstruction, and hematemesis, which appear acutely. Approximately 50\% of patients can also present with an abdominal mass [15-17]. Previous studies discussed a chronic form of JGI, which may mimic the acute form, but signs are

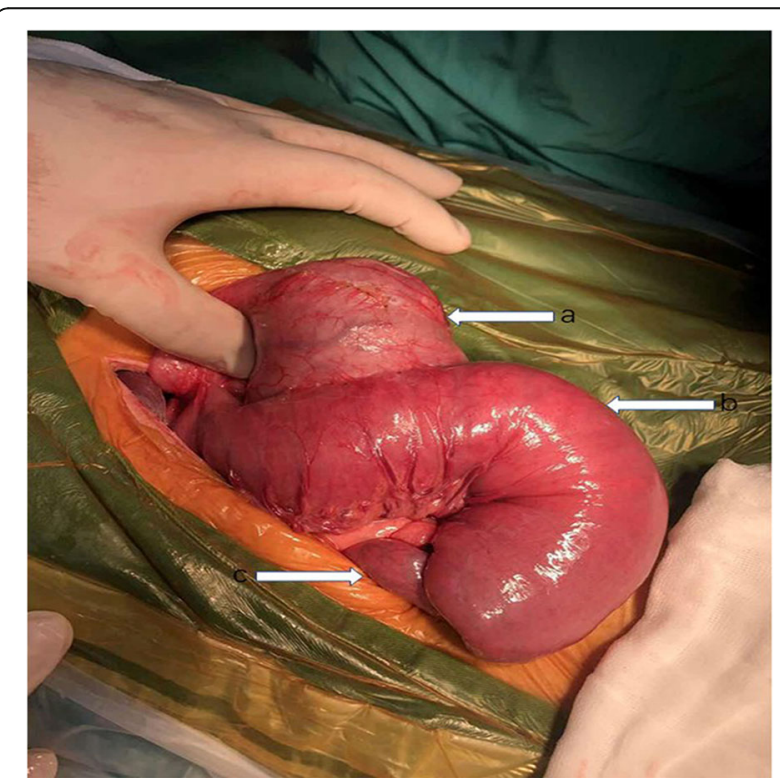

Fig. 3 Operative view demonstrating JGI. Arrow a showed remnant stomach; Arrow b indicates intussusceptum. Arrow C indicates intussusceptien 
milder, transient, and resolve spontaneously [18]. These clinical presentations may help diagnose JGI, which is crucial. Methods of diagnosis include gastroendoscopy, abdominal ultrasonography, and CT. Gastroscopy can provide immediate images and a diagnosis of JGI; however, gastroscopy is not appropriate in patients with peritonitis. Abdominal ultrasonography is widely used in emergency departments but cannot be used to diagnosis JGI because of profuse intestinal and gastric gas. Computed tomography can also provide immediate images of abdominal pathological findings [19], and may be the most useful method because CT can also evaluate the viability of the intestine.

According to Shackman's classification, JGI is classified into three types: type I: afferent loop intussusception; type II: efferent loop intussusception; and type III: both loops are involved in the intussusception [2]; efferent loop intussusceptions occur in $70 \%$ of patients with JGI [20]. Brynitz and Rubinstein suggested a more detailed approach: type1: afferent loop intussusception; type 2a: efferent loop intussusception; type 2b: efferentefferent loop intussusception; type 3: combined types 1 and 3; and type 4: intussusception through Braun's side in a jejunojejunal anastomosis [21]. Our patient fulfilled the criteria for type II or type $2 \mathrm{a}$ according to Brynitz and Rubinstein's classification.

The etiology of JGI is unclear, and several possible mechanisms have been proposed, namely, a long afferent or efferent loop, high acidic state, increased intraabdominal pressure, and shortening of the jejunal mesentery [22]. In terms of surgery, the technique of digestive tract reconstruction, such as the size of gastrojejunostomy, the length of afferent or efferent loop, may play important role in the formation of JGI. however, none of these mechanisms have been confirmed. In some patients, retrograde peristalsis was considered the cause of type II JGI [3, 22]. Additionally, the laxity of mesentery may be related to the JGI.

Early treatment for JGI is crucial because of the high risk of incarceration and strangulation; delayed treatment can lead to serious consequences and even death. Prompt surgery remains the most important treatment and should be considered in every patient with JGI. Surgical procedures for JGI include reduction, resection, and reconstruction of the anastomosis. The mortality rate is linked to operation time; previous studies reported a mortality of approximately $50 \%$ with operation times $>48 \mathrm{~h}$ compared with $10 \%$ for operation times $<48 \mathrm{~h}$ [23]. The choice of surgical procedure depends on the operative findings, and the most important point is judging the viability of the intussusceptum. Endoscopic treatment for JGI has been suggested in some case reports; however, this treatment is associated with a significant risk of recurrence $[4,5,24]$.

In conclusion, JGI is a rare but potentially fatal complication after gastric surgery, especially following Whipple's procedure. Early diagnosis and treatment are crucial, and surgery is considered the most effective treatment for JGI.

\section{Abbreviations \\ JGI: Jejunogastric intussusceptions; CT: Computed Tomography; US: Ultrasound}

\section{Acknowledgements}

We thank Jane Charbonneau, DVM, from Liwen Bianji, Edanz Group China (www.liwenbianji.cn/ac), for editing the English text of a draft of this manuscript.

\section{Authors' contributions}

Author contributions: YXL and YMX searched the literature. YXL conceived of the study, participated in its design and drafted the manuscript, and final revision of the manuscript. YMX and YXL participated in the collection of the clinical data and design of the study. All authors read and approved the final manuscript.

\section{Funding}

Not appliciable.

\section{Availability of data and materials \\ Not applicable.}

Ethics approval and consent to participate

Not applicable.

\section{Consent for publication}

Written informed consent was obtained from the patient for publication of this Case report and any accompanying images. A copy of the written consent form is available for review by the Editor of this journal.

\section{Competing interests}

The authors declare that they have no competing interests.

Received: 17 May 2019 Accepted: 31 March 2020

Published online: 10 April 2020

\section{References}

1. Wheatley MJ. Jejunogastric intussusception diagnosis and management. J Clin Gastroenterol. 1989;11(4):452-4.

2. Monroe LE, Murry JW. Retrograde jejunogastric intussusception. South Med J. 1979;72(5):541-4.

3. Waits JO, Beart RW Jr, Charboneau JW. Jejunogastric intussusception. Arch Surg. 1980;115(12):1449-52.

4. Kochhar R, Saxena R, Nagi B, Gupta NM, Mehta SK. Endoscopic management of retrograde jejunogastric intussusception. Gastrointest Endosc. 1988:34(1):56-7.

5. Toth E, Arvidsson S, Thorlacius H. Endoscopic reduction of a jejunogastric intussusception. Endoscopy. 2011:43(Suppl 2 UCTN):E63.

6. Bozzi E. B: AcadMed. 1914;122:3-4.

7. Kawano F, Tashiro K, Nakao H, Fujii Y, Ikeda T, Takeno S, Nakamura K, Nanashima A. Jejunogastric intussusception after distal gastrectomy with roux-en-Y reconstruction: a case report. Int J Surg Case Rep. 2018;44:105-9.

8. Hsu KF, Chang WK, Chen CJ. A palpable abdominal mass presenting as acute abdomen. Diagnosis: Jejunogastric intussusception. Gastroenterology. 2011;141(4):e11-2.

9. Ahmed T, Ali AA, Jahan M. Acute abdomen 10 years after surgery for duodenal ulcer disease. Mymensingh Med J. 2012;21(2):340-3.

10. Cipe G, Malya FU, Hasbahceci M, Ersoy YE, Karatepe O, Muslumanoglu M. Jejunogastric intussusception: a rare complication of gastric surgery. Case Rep Surg. 2013;2013:838360. 
11. Sahoo MR, Bhaskar V, Mohapatra V. Retrograde jejunogastric intussusception with jejunojejunal intussusception (double telescoping). BMJ Case Rep. 2013;5(15):1-3

12. Gopal R, Elamurugan TP, Hage S, Muthukumarassamy R, Kate V. Retrograde jejunogastric intussusception following Braun's jejunojejunostomy. World J Clin Cases. 2014;2(1):24-6.

13. Jain BK, Garg PK. Gangrenous Jejunogastric intussusception: is reduction advisable? Indian J Surg. 2015;77(6):564.

14. Loi CM, Huang SY, Chen YD, Chen SD, Wu JM, Chen KH. Retrograde jejunogastric intussusception: a case report and review of the literature. Asian J Surg. 2017:40(4):309-12.

15. Foster DG. Retrograde jejunogastric intussusception; a rare cause of hematemesis; review of the literature and report of two cases. AMA Arch Surg. 1956;73(6):1009-17.

16. Vaidya $Y$, Vaithianathan R. A rare case of jejunogastric intussusception following gastric surgery. Int I Surg Case Rep. 2017;31:103-5.

17. Jegadeesan $R$, Sundararajan T, Sidorenko E. Jejunogastric intussusception with jejunojejunal intussusception (double telescoping). Clin Gastroenterol Hepatol. 2018;16(9):e94.

18. Olsen AK, Harbitz TB, Ogreid P, Liavag I. Jejunogastric invagination as a complication after stomach surgery. Tidsskrift for den Norske laegeforening : tidsskrift for praktisk medicin, ny raekke. 1983;103(30):2048-9.

19. Hammond E, Khurana A, Shridhar V, Dredge K. The role of Heparanase and Sulfatases in the modification of Heparan sulfate proteoglycans within the tumor microenvironment and opportunities for novel Cancer therapeutics. Front Oncol. 2014:4:195.

20. Ravirajendran S, Munnamgi S, Abdul A. Antegrade jejunojejunal intussusception inside a retrograde jejunogastric intussusception (double intussusception)-A rare case report. Int I Surg Case Rep. 2017;39:264-6.

21. Brynitz S, Rubinstein E. Hematemesis caused by jejunogastric intussusception. Endoscopy. 1986;18(4):162-4.

22. Irons HS Jr, Lipin RJ. Jejuno-gastric intussusception following gastroenterostomy and vagotomy. Ann Surg. 1955;141(4):541-6.

23. Hovelius L. Jejunogastric intussusception after gastric resection. A report of two cases. Acta Chir Scand. 1971;137(5):491-4

24. Guadagni S, Pistoia M, Catarci M, Carboni F, Lombardi L, Carboni M. Retrograde jejunogastric intussusception: is endoscopic or surgical management more appropriate? Surg Today. 1992;22(3):269-72.

\section{Publisher's Note}

Springer Nature remains neutral with regard to jurisdictional claims in published maps and institutional affiliations.

Ready to submit your research? Choose BMC and benefit from:

- fast, convenient online submission

- thorough peer review by experienced researchers in your field

- rapid publication on acceptance

- support for research data, including large and complex data types

- gold Open Access which fosters wider collaboration and increased citations

- maximum visibility for your research: over $100 \mathrm{M}$ website views per year

At $\mathrm{BMC}$, research is always in progress.

Learn more biomedcentral.com/submissions 